\title{
X-ray Induced Genetic Variability in Amaranthus hybridus L. and Analysis of Variants Using Morphological and Random Amplified Polymorphic DNA Data
}

\author{
Beluchukwu Joseph Nwankwo', Garuba Omosun ${ }^{1}$, Hilary Odo Edeoga1, Odoligie Imarhiagbe ${ }^{2}$, \\ Jeffrey Iyare Omoruyi ${ }^{3}$, Edeji Franklin Uzodinma ${ }^{4}$ \\ ${ }^{1}$ Department of Plant Science and Biotechnology, Michael Okpara University of Agriculture, Umudike, Nigeria \\ ${ }^{2}$ Department of Biological Sciences, Edo University, Iyamho, Nigeria \\ ${ }^{3}$ Rubber Research Institute of Nigeria, Iyanomo, Nigeria \\ ${ }^{4}$ Department of Biotechnology, Federal Institute of Industrial Research, Oshodi, Nigeria
}

Email address:

belunwankwo@gmail.com (B. J. Nwankwo),omosun@yahoo.co.uk (G. Omosun), professoredeoga@yahoo.com (H. O. Edeoga), odoligie.imarhiagbe@yahoo.com (O. Imarhiagbe), jeff4wonders@gmail.com (J. I. Omoruyi),edejiuzodinma@yahoo.com (E. F. Uzodinma)

${ }^{*}$ Corresponding author

To cite this article:

Beluchukwu Joseph Nwankwo, Garuba Omosun, Hilary Odo Edeoga, Odoligie Imarhiagbe, Jeffrey Iyare Omoruyi, Edeji Franklin Uzodinma. X-ray Induced Genetic Variability in Amaranthus hybridus L. and Analysis of Variants Using Morphological and Random Amplified Polymorphic DNA Data. International Journal of Genetics and Genomics. Vol. 7, No. 2, 2019, pp. 18-26.

doi: $10.11648 /$ j.ijgg.20190702.11

Received: April 5, 2019; Accepted: May 28, 2019; Published: June 26, 2019

\begin{abstract}
Amaranthus hybridus L. is an important vegetable in Nigeria, grown mainly for its highly nutritious leaves. In a bid to explore the possibility of increasing the infra-specific diversity of the crop, we induced three accessions of $A$. hybridus from Anambra State, Nigeria with $\mathrm{x}$-ray particles using various concentration levels. The experimental layout composed a $5 \mathrm{x}$ 3 x 3 Randomized Complete Block Design arrangement, with treatment levels: 1 MGY, 2 MGY, 4 MGY, and 6 MGY, selectively allotted to the different accession based on a preliminary dosimetry test. Morphological data were recorded and subsequently leaves samples subjected to Deoxyribonucleic Acid (DNA) extraction and Random Amplified Polymorphic DNA (RAPD) analysis. The results show that except for inflorescence weight, other morphological data were not statistically significant. However, RAPD techniques identify some variations induced by $\mathrm{x}$-ray particles on the different accessions. Ogbunike accession irradiated with $4 \mathrm{MGY}$ appears to show the optimum concentration of $\mathrm{x}$-ray particles required to induce genetic variability in $A$. hybridus. These findings are of paramount importance to plant breeders, whose primary tool is to identify variations to produce better yielding varieties.
\end{abstract}

Keywords: X-Ray, Amaranthus hybridus L., Genetic Variability, Mutation, Diversity, RAPD

\section{Introduction}

Genetic variation is advantageous to a population because it enables some individuals to adapt to the environment at the same time, ensuring population survival in the ever changing environmental condition [1-2]. From an anthropocentric perspective, such genetic variability offers variable traits for breeding selection and plant genetic resources improvement [3]. Genetic variability in plants is caused by various factors, such as: mutation (which can create entirely new alleles in a population), random mating, random fertilization, and recombination between homologous chromosomes during meiosis (which reshuffles alleles within an organism's offspring). Mutations can have significant effects on the individual when they occur in somatic tissue, but are only inherited if they occur in germ-line tissue. Mutations in germ-line tissue are of enormous biological importance because they provide the raw material from which natural 
selection produces evolutionary change [4]. More often, these genetic changes are induced by mutagenic agents such as X-rays, gamma rays, beta rays, neutrons, chemicals, high temperature and low $\mathrm{pH}$ [5]. Plants sometimes transmit somatic mutations to their descendants asexually or sexually (in case when flower buds developments in somatically mutated part of plant). Mutations create variations in the gene pool, and the less favorable (or deleterious) mutations are removed from the gene pool by natural selection, while more favorable (beneficial or advantageous) ones tend to accumulate, resulting in evolutionary change [6]. Irradiation has been successfully used for mutation breeding in various crops and ornamental plants [37] and has proven an adept means of encouraging the expression of recessive genes and producing new genetic variations [23, 36-38]. A study [22] reported that the height of Zea mays coleoptiles exposed to X-ray doses up to $500 \mathrm{r}$ was not affected and shoots of the plants which received over $800 \mathrm{r}$ showed the effects of irradiation by delay in bursting through the coleoptiles and failure to reach the height attained by their controls during the time of the experiment. The starch and sugar content of Sweet Potato has been improved by mutation breeding [39]. A study [34] mutated Amaranthus caudatus L. with Gamma rays and successfully obtained semi-dwarf and dwarf stature, non-branching pattern, improved protein content and pigment mutations (colour of plants and grains). Taxonomically, these mutations which cause change in the plant phylogeny can lead to the formation of new plant varieties, which needs to be examined and identified appropriately.

The genus Amaranthus, with about 70 species, is characterized by a high degree of morphological diversity and a wide spectrum of adaptability to different ecological conditions [7]. All amaranths are drought resistant $\mathrm{C}_{4}$ photosynthetic plant that can grow well in saline, alkaline, acidic or poor soil. This genus, which originated in the New World, is an ancient crop that was already under cultivation 5000-7000 years ago [8]. The amaranth gene pool involves a diverse group of wild relatives and weedy species, and individual Landrace populations [7]. Recently, amaranth has been described as one of the new world super grains and is gaining popularity among health-conscious consumers in many countries of the world, including the United State and Japan [8]. It has been identified as a very promising food crop because of its exceptional nutritive value as judged by its protein and lipid content, as well as for its essential amino acid composition that has relatively high lysine content [9]. In addition, amaranths are also good sources of minerals and vitamins and they contain nutrient than most of the common cereals and legumes [10]. Cultivated amaranths are used for food grain, medicine, leafy vegetables, forage, ornamental gardening, and other potential uses [11-12]. Amaranths as C4 plants, can contribute to mitigate $\mathrm{CO}_{2}$ concentration, the major provoking greenhouse effects. Because of high biomass production and ability to accumulate heavy metals, they can be used as a renewable energy source and for phytoremediation [13]. It is also used in gluten free diet [14]. Amaranth belongs to the group of plants which genetics are poorly studied [15-19]. Such situation is explained by a complexity of its hybridization, caused by an extremely small size of its reproductive organs and a special constitution of its inflorescence [20]. A careful assessment of available literature has revealed that there is a scarcity of information on the irradiation of Amaranthus spp. especially with X-ray. Application of RAPD analyses widely used in various plant species will allow by passing these difficulties and assist in the investigation of amaranth evolution, taxonomy and genetics. Considering the diverse utility base of this promising plant, we hypothesized that an induce variation in the genome of some naturalized population might result in even greater prospects and adaptability in the face of climate change and human-induced environmental impact. Therefore, the present study was undertaken to investigate the mutagenic effects of different $\mathrm{x}$-ray doses on Amaranthus hybridus L. accessions

\section{Materials and Methods}

The experiment was conducted in an experimental farm behind the Mushroom House, College of Natural Sciences, Michael Okpara University of Agriculture, Umudike. Umudike is located approximately at latitude $05{ }^{0} 29^{1} \mathrm{~N}$, longitudes $07^{0} 32^{1} \mathrm{E}$. Umudike falls within the rainforest zone of southern Nigeria, with a mean altitude of 123 meters. Daily mean temperature ranges from $23^{\circ} \mathrm{C}$ and $32^{\circ} \mathrm{C}$. The field work was carried out between the months of July to September, 2015. The seeds of the Amaranthus accessions used were obtained from various localities (Ezi Ogidi, Ogbunike and Oye Olisa) in Anambra State in June 2015. Samples of the germinated accessions of Amaranthus hybridus L. were properly identified at the Department of Botany herbarium, University of Nigeria, Nsukka.

Table 1. Accessions of Amaranthus hybridus and collection points.

\begin{tabular}{lll}
\hline S/n & Accessions & Collection points (GPS location) \\
\hline 1 & Ezi Ogidi & $6^{0} 12^{\prime} 45.68^{\prime \prime} \mathrm{N} 7^{0} 04^{\prime} 19 \mathrm{E}$ \\
2 & Ogbunike & $6^{0} 09^{\prime} 60.00^{\prime \prime} \mathrm{N} 7^{0} 03^{\prime} 00 \mathrm{E}$ \\
3 & Oye Olisa & $6^{0} 13^{\prime} 60.00^{\prime \prime} \mathrm{N} 7^{0} 03^{\prime} 11 \mathrm{E}$ \\
\hline
\end{tabular}

The accessions were treated with radiations at the Radiology Department of the Federal Medical Centre, Umuahia for treatment. Each accession was divided into six parts to include five treatments and one control. The treatments are $1 \mathrm{MGY}, 4 \mathrm{MGY}, 5 \mathrm{MGY}$, and $6 \mathrm{MGY}$. The accessions were planted and a morphological datum (plant height) was taken weekly for one month [34]. The dosimetry was taken from two points on the graph where the plants did best [32-33]. 


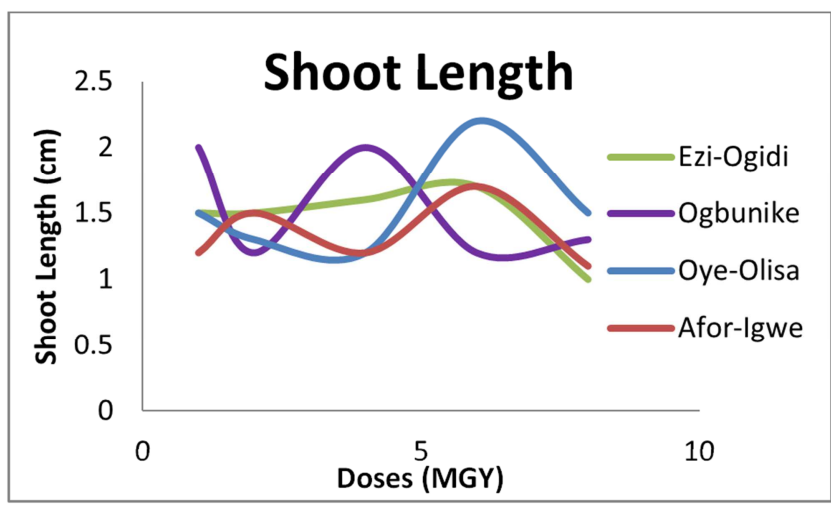

Figure 1. Graphical representation of the dosimetry.

From the graph, it could be deduced that Ezi-Ogidi accession progressed at $5 \mathrm{MGY}$ and $6 \mathrm{MGY}$ while Ogbunike accession did best at $1 \mathrm{MGY}$ and $4 \mathrm{MGY}$. Finally, Oye-Olisa accession progressed at $5 \mathrm{MGY}$ and $6 \mathrm{MGY}$.

\section{Experimental Set Up}

A $5 \times 3$ arrangement was used in a randomized complete block design (RCBD). The factors were X-Ray levels (MGY) with Amaranthus accessions. Each accession was divided into three parts to include two treatments and one control respectively. Ezi Ogidi accession was treated with $5 \mathrm{MGY}$ and $6 \mathrm{MGY}$, Ogbunike accession was treated with $1 \mathrm{MGY}$ and 4 MGY while Oye Olisa accession was treated with 5 MGY and 6 MGY. Each treatment including the control (0 MGY) was replicated four times. Morphological data collected include plant height, number of leaves, leaf area and inflorescence weight.

\section{Data Analysis}

One way analysis of variance was used to test the significance of the treatment and subsequent means compared using Turkey HSD (Highest significant difference).

\section{DNA Extraction}

The DNA of the plant Amaranthus was isolated from the young leaf using the traditional CTAB (Cetyltrimethylammoniumbromide) protocols/ method [35]. Lysing stage: Amaranthus leaf was cut with a scalpel, ground in a mortar and introduced into $600 \mu \mathrm{l}$ of extraction buffer and it was incubated at $65^{\circ} \mathrm{C}$ for 20 minutes. The sample was removed from the incubator and allowed to cool to room temperature and Chloroform was added. The sample was mixed by gentle inversion of the tube several times. Harvest stage: The sample was spun at $14,000 \mathrm{rpm}$ for 15 minutes and the supernatant $(5 \mathrm{~g})$ was transferred into a new eppendorf tube and equal volume of cold Isopropanol was added to precipitate the DNA. The sample was kept in the freezer for 1 hour and later spun at $14,000 \mathrm{rpm}$ for 10 minutes and the supernatant was discarded and the pellet was washed with $70 \%$ ethanol later the sample was air dried for 30 minutes on the bench. The pellet was re-suspended in 100 $\mu l$ of sterile distilled water. DNA concentration of all the samples was measured on spectrophotometer at $260 \mathrm{~nm}$ and $280 \mathrm{~nm}$ and the genomic purity were determined. The genomic purity ranged from $1.8-2.0$ for all the DNA samples. The quality of DNA was detected by agarose gel electrophoresis and the size of fragment obtained was about $25 \mathrm{~kb}$ for all the samples. The DNA was used in PCR amplification using RAPD markers.

\section{PCR Amplification and DNA Electrophoresis}

About $10 \mu \mathrm{l}$ of each DNA was taken into eppendorf tube and $990 \mu \mathrm{l}$ of sterile distilled water was added to make 1000 $\mu 1$. The final concentration became $20-50 \mathrm{ng} / \mu \mathrm{l}$. The reaction mix was carried out in $20 \mu \mathrm{l}$ final volume containing $60 \mathrm{ng}-$ 80 ng DNA, $0.1 \mu \mathrm{M}$ of the primers, $2 \mathrm{MM} \mathrm{MgCl}_{2}, 125 \mu \mathrm{M}$ of each dNTP and 1 unit of Taq DNA polymerase. The thermocycler profiles has an initial denaturation temperature of 3 minutes at $94^{\circ} \mathrm{C}$, followed by 45 cycles of denaturation temperature of $94^{\circ} \mathrm{C}$ for 20 seconds, annealing temperature of $37^{\circ} \mathrm{C}$ for 40 seconds and primer extension temperature of $72^{\circ} \mathrm{C}$ for 40 seconds, followed by final extension temperature at $72^{\circ} \mathrm{C}$ for 5 minutes

Agarose gel electrophoresis was used to determine the quality and integrity of the DNA by size fractionation on $1.0 \%$ agarose gels. Agarose gels were prepared by dissolving and boiling $1.0 \mathrm{~g}$ agarose in $100 \mathrm{ml} 0.5 \mathrm{X}$ TBE buffer solutions. The gels were allowed to cool down to about $45^{\circ} \mathrm{C}$ and $10 \mu \mathrm{l}$ of $5 \mathrm{mg} / \mathrm{ml}$ ethidium bromide was added, mixed together before pouring it into an electrophoresis chamber set with the combs inserted. After the gel has solidified, $3 \mu$ sl of the DNA, $5 \mu \mathrm{l}$ of sterile distilled water and $2 \mu \mathrm{l}$ of $6 \mathrm{X}$ loading dye was mixed together and loaded in the well created. Electrophoresis was done at $80 \mathrm{~V}$ for 2 hours. The integrity of the DNA was visualized and photographed on UV light source.

Table 2. Primer Sequences.

\begin{tabular}{lll}
\hline S/N & Primer Name & Primer Sequences \\
\hline 1 & OPT-06 & CAAGGGCAGA \\
2 & OPT-01 & GGGCCACTCA \\
3 & OPT-20 & GACCAATGCC \\
4 & OPT-07 & GGCAGGCTGT \\
\hline
\end{tabular}

\section{Results}

The effect of different doses of x-ray irradiation on the morphological characters of the three accessions of Amaranthus hybridus L. is depicted in table 3 below. Generally, Ezi Ogidi and Oye Olisa accessions were best induced at $5 \mathrm{MGY}$ and $6 \mathrm{MGY}$ concentrations, however, Ogbunike accessions were best induced at 1 MGY concentration. An evaluation of the Oye Olisa accession reveals that the mean plant height of control was $(65.1 \pm 9.4)$ 
$\mathrm{cm}$ while those recorded in $5 \mathrm{MGY}$ and $6 \mathrm{MGY} \mathrm{x}$-ray irradiation doses decreased from $(60.3 \pm 9.1) \mathrm{cm}$ to $(56.6 \pm$ $7.7) \mathrm{cm}$ respectively. Leaf area was also highest $(15.1 \pm 1.4)$ $\mathrm{cm}^{2}$ in the accession used as control, followed by $5 \mathrm{MGY}$ irradiated plant $(14.5 \pm 1.4) \mathrm{cm}^{2}$ and lowest $(12.3 \pm 1.3) \mathrm{cm}^{2}$ in the $6 \mathrm{MGY} \mathrm{x}$-ray irradiated plant. A similar trend was also noticed when leaf number of the accession was measured, $17.1 \pm 1.1$ mean size was recorded in the control, while $16.7 \pm$ 1.1 and $16.7 \pm 1.2$ were obtained in the Amaranthus accession irradiated at $5 \mathrm{MGY}$ and $6 \mathrm{MGY}$ respectively. The $\mathrm{X}$-ray radiation had a statistical significant on the fresh and dry inflorescence weight of Ezi Ogidi accessions. Under no irradiation (control), fresh and dry inflorescence weights were recorded at $36.43 \mathrm{~g}$ and $6.80 \mathrm{~g}$ respectively. The highest fresh and dry inflorescence weight was recorded in $6 \mathrm{MGY}$ irradiated accession as $44.9 \mathrm{~g}$ and $11.6 \mathrm{~g}$ respectively. 5MGY irradiated accession was lower at $31.8 \mathrm{~g}$ and $6.3 \mathrm{~g}$ for fresh and dry flower weight respectively versa.

The results of the morphological effect of $\mathrm{x}$ - ray irradiated Amaranthus (Ogbunike accession) showed inverse response as the mutagen levels increases. The no irradiated accession (control) produced the lowest mean height $(54.9 \pm 7.7) \mathrm{cm}$, followed by the same accession irradiated at $1 \mathrm{MGY}(57.5 \pm$ 7.6) $\mathrm{cm}$, treatment $4 \mathrm{MGY}$ resulted in the highest plant height value of $(67.2 \pm 8.06) \mathrm{cm}$. Leaf area was high $(14.2 \pm 0.1)$ $\mathrm{cm}^{2}$ in the accession without irradiation (control), but reduced at x-ray irradiation of $1 \mathrm{MGY}(14.2 \pm 0.2) \mathrm{cm}^{2}$ but was stimulated to $(16.1 \pm 0.5) \mathrm{cm}^{2}$ with increased irradiation up to $4 \mathrm{MGY}$. Control produced the highest number of leaves at $16.7 \pm 1.01$ followed by $4 \mathrm{MGY}$ irradiated accession (16. 4 $\pm 1.0)$ while $(16.6 \pm 0.98)$ number of leaves were produced by the accession irradiated 1MGY. However, the above morphological parameters of accession-Ogbunike were not statistically significant at $\mathrm{p}=0.05$. The $\mathrm{x}$-ray radiation had a statistical significant on the fresh and dry inflorescence weight of Ogbunike accession. The average fresh and dry inflorescence weight for the Ogbunike accession as recorded for control gave the highest (44.01 and 10.9) g respectively. 4 MGY irradiated accession gave fresh and dry flower weight of (32.88 and 9.4) g respectively. While fresh and dry flower weight of Ogbunike of 1 MGY x-ray irradiated accession was apparently low at (32.12 and 7.2) g respectively.

The results of the effect of X-ray on Amaranthus (Oye Olisa) accession shows 5 MGY x-ray irradiated accessions had the highest height of $(67.5 \pm 9.2) \mathrm{cm}$, followed by the control $(66.8 \pm 8.4) \mathrm{cm}$, but the accession that received 6 MGY x-ray irradiation showed the lowest mean height of $(54.9 \pm 8.1) \mathrm{cm}$. Leaf area of no-irradiation (control) of this accession was low at $(13.0 \pm 1.4) \mathrm{cm}^{2}$, but stimulated by $5 \mathrm{MGY}$ level of irradiation at $(14.1 \pm 1.4) \mathrm{cm}^{2}$ and also decreased to $(13.5 \pm 1.3) \mathrm{cm}^{2}$ at the irradiation of 6MGY. On the other hand, control gave the highest number of leaf (17.2 $\pm 1.1)$, followed by the accession irradiated at $5 \mathrm{MGY}(16.9 \pm$ $1.03)$, but slightly decreased to $16.8 \pm 1.2$ at $\mathrm{x}$-ray irradiation of 6 MGY. However, the above morphological parameters of accession-Oye Olisa were not statistically significant at $\mathrm{p}=0.05$. The fresh and dry inflorescence weight of the Oye Olisa accession with treatment 5 MGY irradiated Amaranthus accession produced the highest $(65.19 \mathrm{~g})$ fresh weight, but second in dry weight (13.49 g). Accession with no irradiation produced highest fresh inflorescence weight of $61.8 \mathrm{~g}$ and highest dry flower weight value of $16.4 \mathrm{~g}$. X-ray irradiation at $6 \mathrm{MGY}$ had the lowest weight of $36.81 \mathrm{~g}$ and $7.47 \mathrm{~g}$ for fresh inflorescence and dry flower weight respectively.

Table 3. Treatment means and standard error of growth parameters for the different accessions.

\begin{tabular}{|c|c|c|c|c|c|c|c|c|c|}
\hline \multirow{2}{*}{$\begin{array}{l}\text { Morphological } \\
\text { characters }\end{array}$} & \multicolumn{3}{|l|}{ Ezi Ogidi } & \multicolumn{3}{|l|}{ Ogbunike } & \multicolumn{3}{|l|}{ Olisa } \\
\hline & control & 5 MGY & 6 MGY & control & 1 MGY & 4 MGY & control & 5 MGY & 6 MGY \\
\hline Plant height & $65.5^{\mathrm{a}} \pm 9.4^{\mathrm{a}}$ & $60.3^{\mathrm{a}} \pm 9.2$ & $56.6^{\mathrm{a}} \pm 8.06$ & $54.9^{\mathrm{a}} \pm 7.7$ & $57.5^{\mathrm{a}} \pm 7.6$ & $67.2^{\mathrm{a}} \pm 8.6$ & $66.8 \pm 8.4^{\mathrm{a}}$ & $67.5^{\mathrm{a}} \pm 9.2$ & $54.6^{\mathrm{a}} \pm 8.1$ \\
\hline Leaf area & $15.1^{\mathrm{a}} \pm 1.4$ & $14.5^{\mathrm{a}} \pm 1.4$ & $12.3^{\mathrm{a}} \pm 1.3$ & $15.3^{\mathrm{a}} \pm 3.1$ & $14.2^{\mathrm{a}} \pm 0.2$ & $16.1^{\mathrm{a}} \pm 0.5$ & $13.6^{\mathrm{a}} \pm 1.4$ & $14.5^{\mathrm{a}} \pm 1.4$ & $13.5^{\mathrm{a}} \pm 1.3$ \\
\hline Leaf number & $17.1^{\mathrm{a}} \pm 1.1$ & $16.7^{\mathrm{a}} \pm 1.1$ & $16.7^{\mathrm{a}} \pm 1.2$ & $16.7^{\mathrm{a}} \pm 1.01$ & $16.4^{\mathrm{a}} \pm 0.8$ & $16.6^{\mathrm{a}} \pm 1.0$ & $17.2^{\mathrm{a}} \pm 1.1$ & $16.9^{\mathrm{a}} \pm 1.3$ & $16.8^{\mathrm{a}} \pm 1.2$ \\
\hline $\begin{array}{l}\text { Inflorescence } \\
\text { weight wet }\end{array}$ & $36.43^{\mathrm{b}} \pm 1.1$ & $31^{\mathrm{a}} .89 \pm 1.8$ & $44.94^{\mathrm{c}} \pm 2.1$ & $44.01^{\mathrm{c}} \pm 1.1$ & $32.12^{\mathrm{a}} \pm 1.8$ & $32.88^{\mathrm{b}} \pm 2.1$ & $61.8^{\mathrm{b}} \pm 1.1$ & $65.9^{\mathrm{c}} \pm 1.8$ & $36.8^{\mathrm{a}} \pm 2.1$ \\
\hline $\begin{array}{l}\text { Inflorescence } \\
\text { weight dry }\end{array}$ & $6.8^{\mathrm{b}} \pm 2.1$ & $6.3^{\mathrm{a}} \pm 1.1$ & $11.6^{\mathrm{c}} \pm 2.1$ & $10.9^{c} \pm 2.1$ & $7.21^{\mathrm{a}} \pm 2.1$ & $9.4^{\mathrm{b}} \pm 2.1$ & $16.4^{\mathrm{c}} \pm 4.5$ & $13.9^{\mathrm{b}} \pm 1.1$ & $7.4^{\mathrm{a}} \pm 2.3$ \\
\hline
\end{tabular}

HSD $=95 \%$, similar superscript, $a=$ shows no Significant Difference, different superscript shows significant difference .

The scoring of bands was carried out to mark genetic differences among the various accessions. The electrophoretic banding pattern presented in below (table 4) shows that Ezi Ogidi accession irradiated at $5 \mathrm{MGY}$ indicates a genetic banding at locus-4 with no irradiation (control) accession, at $6 \mathrm{MGY}$, bands were visible at loci -1 and -5 , however, at but bands at $-2,-3$, and -6 loci with 5 MGY accession. Ogbunike accession shows a completely different banding pattern with the control indicating that mutation occurred at a very high frequency. $1 \mathrm{MGY}$ irradiation is banded with the control at loci $-1,-5,-7,-9$, and -10. 4 MGY irradiation showed banding pattern with control at $-3,-4$ and -6 loci. But differ from 1 MGY irradiation at $-1,-3,-4,-7,-8$, -9 and -10 . Oye Olisa accession shows a similar banding pattern with the mutant Ezi Ogidi accession. Intra class banding implies that $5 \mathrm{MGY}$ irradiation shows banding with the control at locus -5 only, while 6 MGY irradiation indicated a variant mutant plant and shows no banding with the control, but differ from 5 MGY accession only at locus-5. 
Table 4. Band matrix among the different accessions in relation to the associated irradiation levels.

\begin{tabular}{lllllllllll}
\hline Accessions & Band-1 & Band-2 & Band-3 & Band-4 & Band-5 & Band-6 & Band-7 & Band-8 & Band-9 & Band-10 \\
\hline Ezi Ogidi Control & 1 & 1 & 1 & 0 & 1 & 1 & Ms & Ms & $\mathrm{ms}$ & Ms \\
Ezi Ogidi 5 MGY & 0 & 0 & 0 & 0 & 0 & 0 & $\mathrm{Ms}$ & $\mathrm{Ms}$ & $\mathrm{ms}$ & $\mathrm{Ms}$ \\
Ezi Ogidi 6 MGY & 1 & 0 & 0 & 1 & 1 & 0 & $\mathrm{Ms}$ & Ms & $\mathrm{ms}$ & Ms \\
Ogbunike Control & 0 & 0 & 0 & 0 & 1 & 0 & 1 & 1 & 0 & 0 \\
Ogbunike 1 MGY & 0 & 1 & 1 & 1 & 0 & 1 & 0 & 1 & 0 & 0 \\
Ogbunike 4 MGY & 1 & 1 & 0 & 0 & 1 & 0 & 0 & 0 & 1 & 1 \\
Oye Olisa Control & 1 & 1 & 1 & 1 & 1 & 1 & $\mathrm{Ms}$ & $\mathrm{Ms}$ & $\mathrm{ms}$ & Ms \\
Oye Olisa 5 MGY & 0 & 0 & 0 & 0 & 1 & 0 & $\mathrm{Ms}$ & $\mathrm{Ms}$ & $\mathrm{ms}$ & $\mathrm{Ms}$ \\
Oye Olisa 6 MGY & 0 & 0 & 0 & 0 & 0 & 0 & $\mathrm{Ms}$ & $\mathrm{Ms}$ & $\mathrm{ms}$ & $\mathrm{Ms}$ \\
\hline
\end{tabular}

Five primers were used for the preliminary study, out of which two primers (T-06 and T-20) gave the best polymorphism. The cultivar has three bands degraded with the use of $5 \mathrm{MGY}$ and $6 \mathrm{MGY}$ with primer T-06; the bands are $1500 \mathrm{bp}, 1400 \mathrm{bp}$ and $800 \mathrm{bp}$. This is shown on plate 1. Two primers T-06 and T-20 gave polymorphism
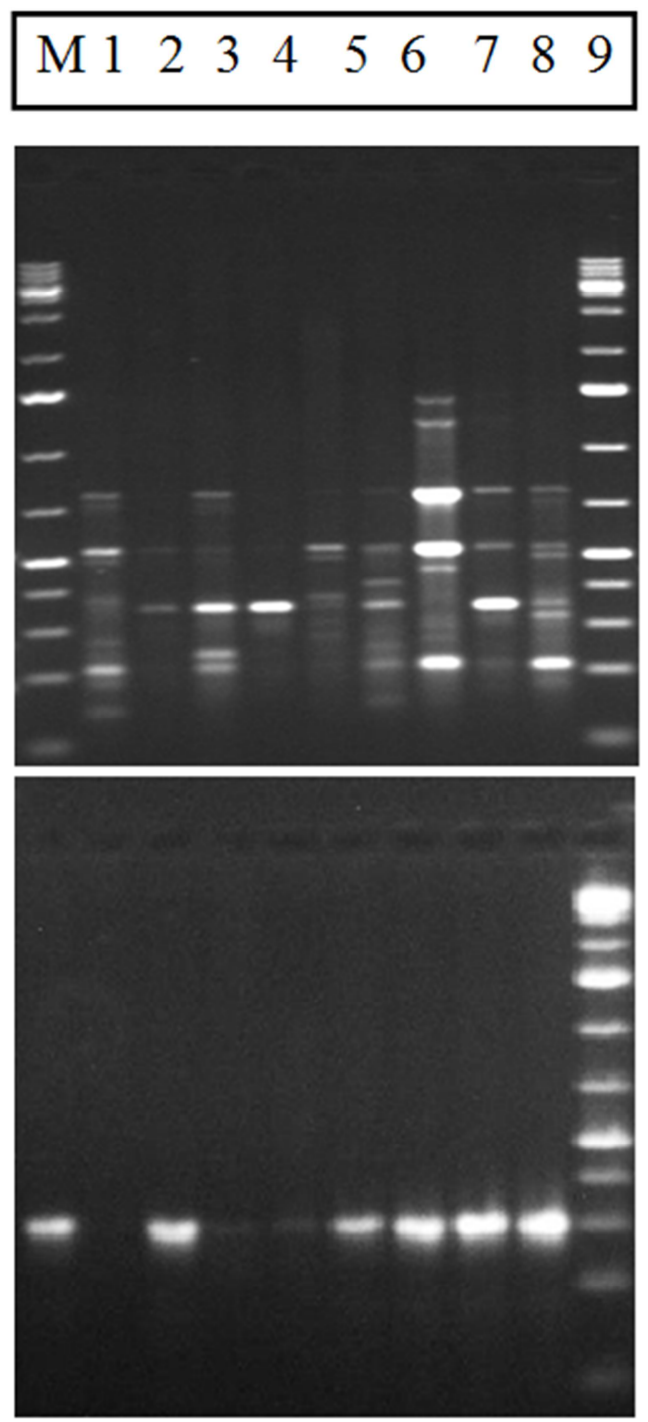

Figure 2. Gel electrophoresis for primer OPT-06, OPT-20, OPT-07, OPT-01.

1 Ezi Ogdi Control2 Ezi Ogdi 5mGY 3 Ezi Ogdi 6mGY4 Ogbunike Control.

5 Ogbunike $1 \mathrm{mGY} 6$ Ogbunike 4mGY 7 Oye Olisa Control.

8 Oye Olisa 5mGY 9 Oye Olisa 6Mgy.
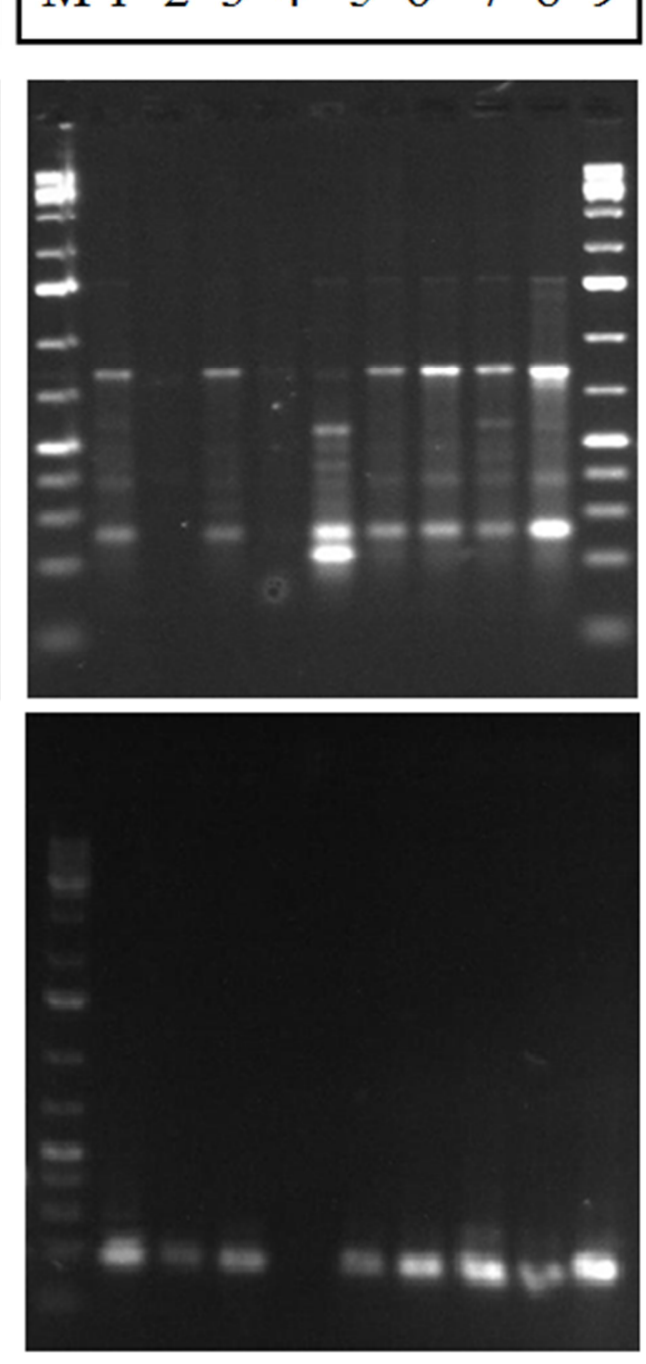

with Ogbunike samples. Control sample had many missing or absent bands on primer T-06 shown on plate 1 . Primer T-20 had one band present on Ogbunike 1 MGY and absent on others. Ezi Ogidi samples had two polymorphic bands with primer T-06. The size of the two bands is 400 bp and 200 .

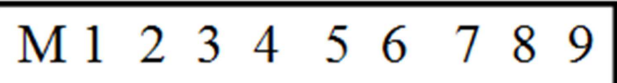




\section{Distance}

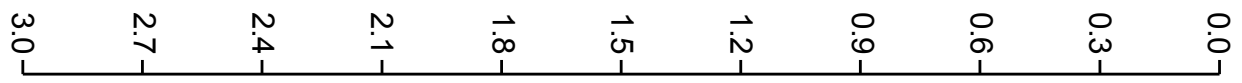

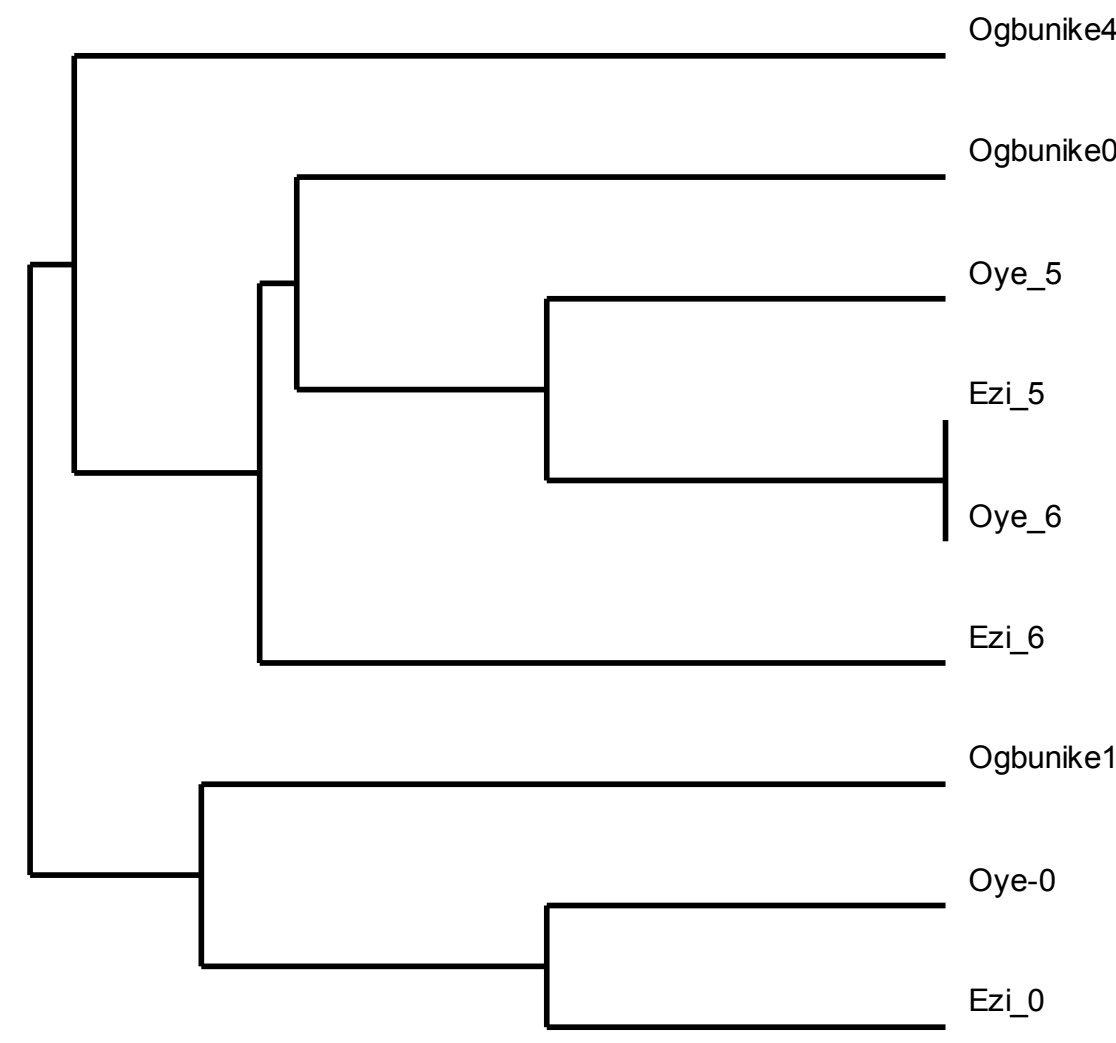

Figure 3. Dendogram representing the genetic diversity among different accessions using RAPD.

Legend: Eze_0=Ezi Ogidi Control, Eze_ $5=$ Ezi Ogidi 5 MGY, Eze_6 = Ezi Ogidi 6 MGY, Ogbunike $0=$ Ogbunike Control, Ogbunike1 = Ogbunike 1 MGY, Ogbunike 4 = Ogbunike 4 MGY, Oye_0 = Oye Olisa Control, Oye_5 = Oye Olisa 5 MGY, Oye_6 = Oye Olisa 6 MGY.

\section{Discussion}

The exploitation of natural and induced genetic diversity inherent in crop plant species is a basic requirement for plant breeding activities. The huge pressure exerted on supporting natural resources as a result of population increase has prompted the need for proper plant genetic resource management plans to sort for relevant variations in available crop plants that can be of immense benefit to plant breeders, for crop improvement. One way of inducing variability in crop plants is by X-ray irradiation. The present research work was carried out to determine the effect of different doses of X-ray irradiation on three (3) accessions of Amaranthus hybridus L. using morphological and molecular (RAPD) methods.

From the morphological data, it was discovered that there was no statistical difference in three of the four parameters assessed (plant height, leaf area, and leaf number) in all accessions (Ezi-Ogidi, Ogbunike and Oye-Olisa) subjected to $\mathrm{X}$-ray treatment. This finding was in line with the assertion of [21] who stated that X-ray radiation has no effect on the seed germination or growth of Echinacea angustifolia. Russel [22], also recorded no difference in the plant height of Zea mays exposed to X-ray. Although morphological characters in Amaranthus hybridus are important, going by its major use as a vegetable crop, the variation induced might not be morphologically obvious but could be at the biochemical level in terms of nutrient level improvement. The wet and dry weight of the inflorescence was statistically significant. Inflorescence of Amaranthus hybridus is a vital part of the plant, primarily for reproduction and also for the utilization of its seeds as an important grain crop for food security. It appears to be like the different concentrations of exerted differential effects on the different accession types. Notably, Treatment 6 MGY resulting in the highest weight value of the inflorescence for Ezi-Ogidi accession, treatment 5 MGY produced the best inflorescence weight for Oye-Olisa accession. However, the treatment I MGY and 4 MGY did not improve the weight of Ogbunike accession. In line with this result, it is best to apply specific concentration of X-ray on the particular accession based on the requirement as regards the weight of the inflorescence. This finding is in line with the work of El-Mokadem and Mostafa [23] on 
Browallia speciosa mutated with Sodium azide as well as ElNashar [24] on Amarathus seedlings and Mostafa [25] on Heliathus annuus.

Molecular analyses have helped resolve the distinctness in the genetic makeup of crop plants when morphological investigations have failed [26]. The present study involving the use of Random amplified polymorphic DNA has helped in identifying mutants and appropriate concentration needed for the specific accession. From the DNA result, it was noticed that Oye Olisa accession treated with $5 \mathrm{MGY}$ and 6 MGY has three bands of $1500 \mathrm{bp}, 1400 \mathrm{bp}$, and $800 \mathrm{bp}$ with primer T-06 which is not noticed in the control. The Ogbunike control sample had many missing or absent bands on primer T-06, unlike the treated samples. Ogbunike accession treated with $1 \mathrm{MGY}$ had one band on primer T-20 which is absent on others. Ezi Ogidi accessions had two polymorphic bands of $400 \mathrm{bp}$ and $200 \mathrm{bp}$ with primer T-06.

The genetic variability using a distance matrix dendrogram clearly depicted in figure 2 outlines the genetic relationship among the different accessions. The dendrogram comprises 3 major groups of similar genetic make-up. The first clade is composed solely of the Ogbunike accession irradiated with $4 \mathrm{MGY}$. The second clade is composed of Ogbunike (control), Oye Olisa accession irradiated with $5 \mathrm{MGY}$ and $6 \mathrm{MGY}$, and Ezi Ogidi accession irradiated with 6 MGY. The third clade comprises Ogbunike accession irradiated with 1 MGY, Ezi Ogidi accessions (control), and Oye Olisa accession (control). This genetic relationship identifies Ogbunike accession irradiated with $4 \mathrm{MGY}$ as the most genetically diverse accession. And this also gives the clue on the best concentration required to induce such mutation, which in this case was $4 \mathrm{MGY}$. Various authors have suggested the use of a rapid and specific molecular marker as a workable solution to solving the problem of ambiguity resulting from the use of morphological method in assessing crop genetic variability. The advantageous use of molecular techniques in identifying variability induced by $\mathrm{x}$-ray particles as compared to the morphological method has been affirmed. It offers a faster and more precise way of determining relationships among closely related species than that of the morphological investigation. These findings are in line with the report of Rahman [31] which states that DNA fingerprinting is an important tool for molecular characterization of various groups of plants. Jimoh et al. [27] went further to explain that morphological characteristics are subject to physiological and environmental influence. Snezana et al. [7] also state that the use of the RAPD assay to identify genetic variation is preferred over the morphological and biochemical markers since these are completely devoid of the effects of the environment and the stage of the experimental material, thus making them highly reliable. On the same note, Park and Nishikawa [8] states that the evaluation of morphology is very time-consuming and morphological traits often cannot serve as unambiguous markers because of environmental influence. It is worthy to also note that that
RAPD is a preferred method for identification of genotypes because it is relatively inexpensive, utilizes arbitrary primers, and randomly samples a potentially larger number of loci in a less complex pattern than other polymerase reaction (PCR) based markers [28-30].

\section{Conclusion}

The study has affirmed the use of x-ray particles in inducing genetic variations in Amaranthus hybridus accessions from Nigeria. Although most of the morphological parameters were statistically not significant except for inflorescent weight. The molecular analysis, however, showed variations, identifying polymorphism among the different accessions. The Oye Olisa accession treated with 5 MGY and 6 MGY has three bands of $1500 \mathrm{bp}, 1400 \mathrm{bp}$, and $800 \mathrm{bp}$ with primer T-06 which is not noticed in the control. The Ogbunike control sample had many missing or absent bands on primer T-06, unlike the treated samples. Ogbunike accession treated with $1 \mathrm{MGY}$ had one band on primer T-20 which is absent on others. This study identifies Ogbunike accession irradiated with $4 \mathrm{MGY}$ as the most genetically diverse accession.

The genetic distinctness identified among accessions is largely due to chromosomal disturbances which is a consequence of the physical mutagen. This has further proven RAPD as an effective tool for the detection of genetic differences among individuals and a useful tool for breeders. The mutagenesis treatments seemed to activate the expression of some genes which resulted in the different appearances of the bands.

Future studies should involve the genetic variability assessment of the second generation mutated plants on agricultural traits such as disease resistance, pigment (leaf and grain colour), branching pattern, yield, taste, nutrition, etc.

\section{References}

[1] Templeton, A. R. (1995). Biodiversity at the molecular genetic level: experiences from disparate macroorganisms. In: Hawksworth D. L. (ed). Biodiversity. Chapman and Hall, London, pp. 59-64.

[2] Frankham, R. (2005). Genetics and extinction. Biological Conservation. 126 (2): 131-140.

[3] Bhandari, H. R., Bhanu, A. H., Srivastava, K., Singh, M. N; Hemantaranjan, S. A. (2017). Assessment of genetic diversity in crop plants- an overview. Advances in Plants \& Agriculture Research, 7 (3): 279-286.

[4] Garrett, R. H. and Grisham, C. M. (2013). Biochemistry. Brook Scole Publishers, United Kingdom, pp 122.

[5] Sen, S. and Kar, D. K. (2009). Cytology and Genetics. Alpha Science International Ltd., UK, pp 404.

[6] Schreiber, M. Stein, N and Masch, M. (2018). Genomic approaches for studying crop evolution. Genome Biology, 19: 140. 
[7] Snezana, D. M., Marija, K., Danijela, R., Milena, S. and Lidija, S. (2012). Assessment of genetic relatedness of the two Amaranthus retroflexus populations by protein and Random Amplified Polymorphic DNA (RAPD) Markers. African Journal of Biotechnology, 11 (29): 7331-7337.

[8] Park, Y. and Nishikawa, T. (2012). Rapid identification of Amaranthus caudatus and Amaranthus hypochondriacus by sequencing and PCR-RFLP analysis of two starch synthase genes. Genome, 55: 623-628.

[9] Akin-Idowu, P. E., Odunola, O. A., Gbadegesin, M. A., Oke, A. and Orkpeh, U. (2013). Assessment of the protein quality of twenty nine grain amaranth (Amaranthus spp. L.) accession using amino acid analysis and one-dimensional electrophoresis. African Journal of Biotechnology, 12 (15): 1802-1810.

[10] Muyonga, J. H., Nabakabya, D., Nakimbugwe, D. N., and Masinde, D. (2008). Efforts to promote amaranth production and consumption in Uganda to fight malnutrition. In: Using Food Science and Technology to Improve Nutrition and Promote National Development. Robertson, G. L. and Lupien, J. R. (eds.). International Union of Food Science and Technology, Vol. 1, pp. 40-42.

[11] Brenner, D., Baltensperger, D., Kulakow, P., Lehmann, J., Myers, R., Slabbert, M., and Sleugh, B. (2000). Genetic resources and breeding of Amaranthus. Plant Breeding Revolution, 19: 227-285.

[12] Yudina, R. S., Zheleznova, N. B., Zakharova, O. V., Zhelenov, A. V., and Shumny, V. K. (2005). Isosyme analysis in a genetic collection of amaranths (Amaranthus L.). Russian Journal of Genetics, 41 (12): 1395-1400.

[13] Hricova, A., Fejer, J., Libiakova, G. and Gajdosova, A. (2012). Adding value to amaranth through the use of radiation mutagenesis. Neglected and Under-Utilized Species Research in $21^{\text {st }}$ Century, pp. 15.

[14] Schoelenchner, R. and Tomoskozi, S. (2012). Use of speciality and underutilized grain species and pseudocereals for glutenfree food production. Neglected and Under-Utilized Species Research in $21^{\text {st }}$ Century, pp. 42-43.

[15] Gudu, S., and Gupta, V. K. (1988). Electophoresis as an aid for identification of various species and cultivars of grains amaranths. Acta Horticult., 218: 230-238.

[16] Gorinstein, S., De Nue, I. A., and Aruda, P. (1991). Alcohol soluble and total proteins from Amaranthus seeds and their comparison with other cereals. Journal of Agriculture, Food and Chemistry, 39: 848-850.

[17] Zheleznov, A. V., Solonenko, L. P., and Zheleznova, N. B. (1997). Seed protein of the wild and cultivated Amarathus species. Euphytica, 97: 177-182.

[18] Drzewiecki, J. (2001). Similarities and differences between Amaranthus species and cultivars and estimation of out crossing rate on the basis of electrophoretic separations of urea- soluble seed proteins. Euphytica, 119 (3): 279-287.

[19] Juan, R., Pastor, J., Alaiz, M. and Vioque, J. R. (2007). Electrophoretic characterization of Amaranthus L. seed proteins and its systematic implication. Botany Journal of Linnaeus Society, 155 (1): 57-63.

[20] Keckesova, M., Mudry, P., Hricova, A., and Galova, Z. (2012). Enzyme polymorphic analysis in irradiated amaranth
(Amaranthus spp.). Neglected and Under-Utilized Species Research in $21^{\text {st }}$ Century, pp. 6-9.

[21] De Clemente, S. (2012). X-ray radiation effects on germination and growth of Echinacea augustifolia. Http://www.google.com. [Accessed on January 6, 2016].

[22] Russell, M. A. (1937). Effect of x-ray on Zea mays. WWW.Plantphysiol.org. [Accessed on January 6, 2016].

[23] El-mokadem, H. E. and Mostafa, G. G. (2014). Induction of mutations in Browallia speciosa using sodium azide and identification of the genetic variation by peroxidase isozyme. African Journal of Biotechnology, 13 (1): 106-111.

[24] El- Nasher, Y. I. A. 2006. Effect of chemical mutagens (sodium azide and diethyl sulphate) on growth, flowering and induced variability in Amaranthus caudatus L. and $A$. hypochondriacus L. Ph. D thesis, Alexandria University, p. 80 .

[25] Mostafa, G. G. (2011). Effect of sodium azide on the growth and variability induction in Helianthus annus L. International Journal of Plant Breeding and genetics, 5 (1): 76-85

[26] Guillermo C. A. Vidal-Russel R., Aizen M. A., Nickrent D. (2014). Genetic diversity and population structure of the mistotle. Plant Systematics Evolution, 300: 153-162.

[27] Jimoh, M. A., Edeoga, H. O. and Omosun, G. (2013). DNA fingerprinting of six Senna Species and the taxonomic implication. International Journal of Advanced Research in Biotechnology, 1 (6): 022-026.

[28] Hadrys, H., Balick, M., and Schierwater, B. (1992). Applications of random amplified polymorphic DNA (RAPD) in molecular ecology. Molecular Ecology, 1: 53-63.

[29] Williams, J. G. K., Hanafey, M. K., Rafalski J. A., and Tingey, S. V. (1993). Genetic analysis using random amplified polymorphic DNA markers methods. Enzymology, 218: 704740 .

[30] Das, M., Bhaitacharya, S., and Pal, A. (2005). Generation and characterization of SCARS by cloning and sequencing of RAPD products: a strategy for specific marker development in bamboo. Annals of Botany, 95: 835-841.

[31] [31] Rahman, M. O. (2007). DNA fingerprinting in Utricularia L. section Ultricularia as revealed by PCR based assay. International Journal of Botany, 3 (1): 56-68.

[32] Anonymous (2016). Procedure for mutation breeding. Http://www.google.com. Accessed on January 6, 2016.

[33] Mba, C. (2013). Induced mutations unleash the potentials of plant genetic resources for Food and Agriculture. Agronomy, 3: $200-231$.

[34] Gomez-Pando, L. (2014). Development of improved varieties of native grains through radiation-induced mutagenesis. In: Mutagenesis: exploring novel genes and pathways. N. B. Tomlekova, M. I. Kozgar and M. R. Wani (eds.). Wageningen Academic Publishers, Wageningen, 105123 Pages.

[35] Doyle, J. J. and Doyle, J. L. (1987). A rapid DNA isolation procedure from small quantities of fresh leaf tissue. Phytochemical Bulletin, 19: 11-15.

[36] Schum, A. (2003). Mutation breeding in ornamental and efficient breeding method. Acta Horticulture, 612: 47-60. 
[37] Song, H. S. and Kang, S. Y. (2003). Application of natural variation and induced mutation in breeding and functional genomics: papers for international symposium: current status and future of plant mutation breeding. Korea Journal of Breeding Science, 35 (1): 24-34

[38] Yoon, K. E., Park, Y. H. and Im, B. G. (1990). Effect of gamma radiation on seed germination and androgenesis in Nicotiana tabacum L. Korean Journal of Breeding Science, 21: 256-262.
[39] Shin, J., Kim, B., Seo, S., Jeon, S. B., Kim, J., Jun, B., Kang, S., Lee, J., Chung, M. and Kim, S. (2011). Mutation breeding of sweet potato by gamma-ray radiation. African Journal of Agricultural Research, 6 (6): 1447-1454. 